\title{
Neurotensin induced inhibition of gastric acid secretion in duodenal ulcer patients before and after parietal cell vagotomy
}

\author{
P S OLSEN, J H PEDERSEN, P KIRKEGAARD, H BEEN, \\ F STADIL, J FAHRENKRUG, AND J CHRISTIANSEN
}

From the Department of Surgery D, Glostrup Hospital; Department of Surgery C, Rigshospitalet; Department of Surgery D, Herlev Hospital; University of Copenhagen; and Department of Clinical Chemistry, Central Hospital, Hillerød, Denmark

SUMmARY The influence of the vagal nerve on the inhibitory effect of neurotensin on pentagastrin stimulated gastric acid secretion was investigated in seven duodenal ulcer patients before and after parietal cell vagotomy without drainage. Preoperatively, neurotensin inhibited gastric acid secretion, whereas no effect was found postoperatively. Plasma concentration of neurotensin was identical pre-and postoperatively. This study shows that the inhibitory effect of neurotensin on gastric acid secretion is dependent on an intact vagal innervation of the parietal cell area.

In the gastrointestinal tract the tridecapeptide neurotensin has been found in peripheral nerves as well as in endocrine cells of the ileal mucosa. ${ }^{12}$ The peptide may act as an enterogastrone, because intraduodenal and intrajejunal instillation of fat inhibited gastric acid secretion and increased plasma concentration of neurotensin. ${ }^{34}$ In addition, intravenous infusion of neurotensin inhibited both pentagastrin stimulated and meal induced gastric acid secretion in healthy subjects. ${ }^{5} 6$

In duodenal ulcer patients intraduodenal fat inhibited gastric acid secretion and increased plasma concentrations of neurotensin but to a lesser degree than in a group of healthy subjects. ${ }^{3}$ When the patients were subjected to parietal cell vagotomy intraduodenal fat did not inhibit gastric acid secretion postoperatively. ${ }^{7}$ This suggests that the acid inhibitory effect of neurotensin depends on the vagal innervation of the parietal cell area. This possibility was tested in this study which reports the effect of intravenous infusion of exogenous neurotensin on gastric acid secretion in duodenal ulcer patients before and after parietal cell vagotomy.

Address for correspondence: Dr P S Olsen, Department of Clinical Chemistry, ML 4051, Rigshospitalet, Blegdamsvej 9, 2100 Copenhagen $\emptyset$, Denmark. Received for publication 22 July 1983

\section{Methods}

\section{PATIENTS}

Two women and five men median age 42 years (total range $29-56$ years) were investigated. All patients had endoscopically verified duodenal ulcer. None had recent complications such as bleeding and perforation or evidence of gastric outlet obstruction. None had earlier been subjected to gastrointestinal surgery. Each patient was investigated before and four to six months after an adequate parietal cell vagotomy according to a standard technique ${ }^{8}$ judged by a more than $80 \%$ reduction of insulin stimulated peak acid output. All patients gave informed consent.

\section{EXPERIMENTAL DESIGN}

After an overnight fast a tube was placed in the stomach under fluoroscopic control. Gastric juice was aspirated in 15 minute periods by intermittent mechanical suction producing a subatmospheric pressure of $150 \mathrm{mmHg}$. The stomach was emptied and after a basal period of 30 minutes, pentagastrin (Peptavlon, ICI, UK) was administered as a continuous intravenous infusion in a dose of 150 $\mathrm{ng} / \mathrm{kg} / \mathrm{h}$ for three hours. This dose of pentagastrin equals $D_{50}$ in normal subjects ${ }^{9}$ and no fade of acid secretion occurs within four hours. ${ }^{10}$ After 90 
minutes of pentagastrin infusion an intravenous infusion of neurotensin (Beckman, Calif, USA) 500 $\mathrm{ng} / \mathrm{kg} / \mathrm{h}$ was added and continued throughout the study. Blood samples for analysis of neurotensin were taken from a cubital vein every 15 minutes.

\section{LABORATORY ANALYSES}

The volume of gastric juice was measured in all aspirates and the concentration of $\mathrm{H}+$ was determined by titration with $0 \cdot 1 \mathrm{~mol} / 1 \mathrm{NaOH}$ to $\mathrm{pH} 7 \cdot 0$ using an autotitrator (ABU-12, Radiometer, Copehagen, Denmark). Plasma neurotensin concentration was determined by radioimmunoassay in unextracted plasma by radioimmunoassay. The antibody used (759 A-4) recognises the midportion and C-terminal part of the neurotensin molecule. It does not cross react with other known gastrointestinal peptides. Monoiodinated neurotensin (125-I (Tyr-3)-NT) was used as tracer and neurotensin (Beckman, Calif, USA) as standard. ${ }^{11}$ Detection limit in plasma was $3 \mathrm{pmol} / \mathrm{l}$ and the working range 3-100 pmol/l. Intraassay and interassay variation was below $15 \%$.

In each gastric sample osmolarity was determined by freezing point reduction as an indicator of duodenogastric reflux.

\section{CALCULATIONS}

Calculations of gastric acid secretion were based on the periods $60-90$ minutes and $150-180$ minutes. All values given are median and total range. The results were evaluated statistically by the Wilcoxon's test for paired observations.

\section{Results}

During infusion of pentagastrin a significant increase in gastric acid secretion was found pre- as well as postoperatively (Fig. 1, Table). Infusion of neurotensin, $500 \mathrm{ng} / \mathrm{kg} / \mathrm{h}$, decreased pentagastrinstimulated acid secretion preoperatively from a median acid output of $23 \mathrm{mmol} \mathrm{H}+/ 30 \mathrm{~min}(19.9-$ $49.9)$ to $11.4 \mathrm{mmol} \mathrm{H}+/ 30 \mathrm{~min}(8 \cdot 5-18.7)(\mathrm{p}<0.01)$. Postoperatively neurotensin had no effect on gastric acid secretion (Fig. 1, Table).

Plasma neurotensin concentrations were identical pre- and postoperatively in the control periods (60-90 minutes) as well as during infusion of neurotensin (150-180 minutes) respectively (Fig. 2).

Duodenogastric reflux occurred in two samples that were excluded from the study. The coefficient of variation of repeated measures in the steady state was between 8 and $10 \%$. Recovery of gastric acid has previously been determined using the present experimental design and was found to be approximately $90 \% .^{10}$

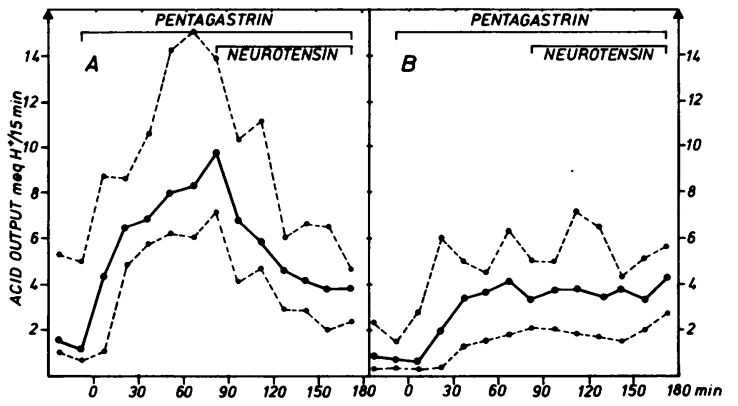

Fig. 1 Gastric acid secretion (mmol $\mathrm{H}+/ 15 \mathrm{~min}$ ) during infusion of pentagastrin $150 \mathrm{ng} / \mathrm{kg} / \mathrm{h}$ and neurotensin 500 $\mathrm{ng} / \mathrm{kg} / \mathrm{h}$. Medians and total range are shown. A: Preoperatively. B: Postoperatively.

\section{Discussion}

Several studies have confirmed that exogenous neurotensin inhibits gastric acid secretion in healthy subjects. ${ }^{56}$ The effect on acid secretion in duodenal ulcer patients, however, has not been investigated.

This study shows that neurotensin inhibits gastric acid secretion in unoperated duodenal ulcer patients to the same extent as previously observed in healthy subjects. ${ }^{6}$ The study also suggests that it is unlikely that the increased acid secretion observed in a large proportion of duodenal ulcer patients ${ }^{12}$ is caused by an impaired inhibitory effect of neurotensin on gastric acid secretion.

The plasma concentrations of neurotensin obtained in this study are slightly above postprandial levels measured with this assay in normal subjects (25-100 pmol/l), but may still be considered to be within a physiological range.

After parietal cell vagotomy the inhibitory effect of neurotensin on acid secretion was abolished although the plasma concentrations of neurotensin

Table Gastric acid output in the basal period, during infusion of pentagastrin and during infusion of pentagastrin and neurotensin in seven duodenal ulcer patients. Medians and total range are shown.

\begin{tabular}{|c|c|c|c|}
\hline Treatment & $\begin{array}{l}\text { Period } \\
\text { (minutes) }\end{array}$ & $\begin{array}{l}\text { Preoperatively } \\
\text { (mmol } \\
\text { H+/30 min) }\end{array}$ & $\begin{array}{l}\text { Postoperatively } \\
\text { (mmol } \\
H+130 \text { min) }\end{array}$ \\
\hline \multirow{3}{*}{$\begin{array}{l}\text { Control } \\
\text { Pentagastrin } \\
\text { Pentagastrin }+ \\
\text { neurotensin }\end{array}$} & $-30-0$ & $2 \cdot 5(0 \cdot 8-5 \cdot 4)$ & $1 \cdot 6(0 \cdot 2-2 \cdot 4)$ \\
\hline & $60-90$ & $23.0(19.9-49.9)$ & $11 \cdot 0(5 \cdot 4-15 \cdot 8)^{*}$ \\
\hline & $150-180$ & $11 \cdot 4(8 \cdot 5-18 \cdot 7)^{*}$ & $10 \cdot 4(5 \cdot 4-13 \cdot 6)$ \\
\hline
\end{tabular}

* $p<0.01$ as compared with infusion of pentagastrin preoperatively. 


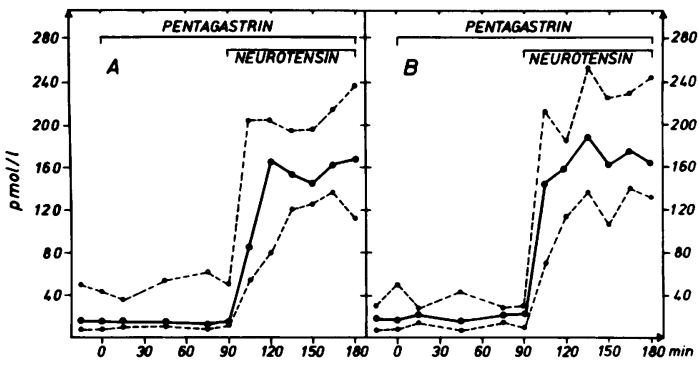

Fig. 2 Plasma neurotensin concentration during infusion of pentagastrin $150 \mathrm{ng} / \mathrm{kg} / \mathrm{h}$ and neurotensin $500 \mathrm{ng} / \mathrm{kg} / \mathrm{h}$. Medians and total range are shown. A: Preoperatively. B: Postoperatively.

were identical in the pre- and postoperative state. The degree of inhibition of stimulated acid secretion might depend on the pre-existing secretory rate.

If, however, the pre-existing secretory rate is $50 \%$ of maximum or less as in this study, it is unlikely that the lack of inhibition by neurotensin postoperatively is dependant on the secretory rate. ${ }^{13}$

The mechanism of action of neurotensin on gastric acid secretion is unknown. The present results are in accordance with observations in dogs where neurotensin inhibited acid secretion by about $60 \%$ in the intact animal, whereas vagal denervation completely eliminated the inhibitory effect of neurotensin. ${ }^{14}$ Neurotensin does not influence histamine stimulated gastric acid secretion ${ }^{15}$ and the present data that parietal cell vagotomy abolish the inhibitory effect of neurotensin suggest that the peptide does not act directly on the parietal cell. The demonstration of neurotensin containing nerves in the stomach $^{16}$ fits with the hypothesis that neurotensin might act at a presynaptic level, but a decreased sensitivity to neurotensin after parietal cell vagotomy cannot be excluded.

Exogenous pancreatic glucagon inhibits meal and gastrin stimulated gastric acid secretion in healthy subjects and duodenal ulcer patients ${ }^{17}$ but does not inhibit histamine stimulated gastric acid secretion. ${ }^{18}$ Like neurotensin the acid inhibitory effect of glucagon is abolished in duodenal ulcer patients after parietal cell vagotomy. ${ }^{19}$ These observations suggest that intact vagal innervation of the parietal cell area is a condition for the function of both these acid inhibitory peptides. Neurotensin, however, might function more as a neurotransmitter than a hormone but this hypothesis needs to be verified by further studies.

This study was supported by the Danish Hospital Foundation for Medical Research Region of
Copenhagen, The Faroe Islands and Greenland (42/81), and the P Carl Petersens Foundation

\section{References}

1 Ferri G-L, Adrian TE, Ghatai MA et al. Tissue localisation and relative distribution of regulatory peptides in separated layers from the human bowel. Gastroenterology 1983; 84: 777-86.

2 Polak JM, Sullivan SN, Bloom SR et al. Specific localisation of neurotensin to the $\mathrm{N}$ cell in human intestine by radioimmunoassay and immunocytochemistry. Nature 1977; 270: 183-4.

3 Kihl B, Rökaeus $\AA$, Rosell S, Olbe L. Fat inhibition of gastric acid secretion in man and plasma concentrations of neurotensin-like immunoreactivity. Scand J Gastroenterol 1981; 16: 513-26.

4 Petersen B, Christiansen J, Rökaeus $\AA$, Rosell S. The effect of intravenous and intrajejunal fat infusion on gastric acid secretion and plasma neurotensin-like immunoreactivity (NTLI) in man. Scand J Gastroenterol 1984. (In press.)

5 Blackburn AM, Fletcher DR, Bloom SR et al. Effect of neurotensin on gastric function in man. Lancet 1980; 1: 987-9.

6 Skov Olsen P, Pedersen JH, Kirkegaard P, Stadil F, Fahrenkrug J, Christiansen J. Neurotensin inhibits meal-stimulated gastric acid secretion in man. Scand $J$ Gastroenterol 1983 18: 1073-6.

$7 \mathrm{Kihl}$ B, Olbe L. Fat inhibition of gastric acid secretion in duodenal ulcer patients before and after proximal gastric vagotomy. Gut 1980; 21: 1056-61.

8 Christiansen J, Jensen H-E, Ejby-Poulsen P, Bardram L, Henriksen FW. Propsective controlled vagotomy trial for duodenal ulcer. Primary results, sequelae, acid secretion, and recurrence rates two to five years after opertion. Ann Surg 1981; 193: 49-55.

9 Christiansen J, Holst JJ, Kalaja E. Inhibition of gastric acid secretion in man by exogenous and endogenous pancreatic glucagon. Gastroenterology 1976; 70: 68892.

10 Petersen B, Christiansen J, Kirkegaard P, Olsen PS. The stability of gastric acid secretion during prolonged pentagastrin-stimulation. Clin Sci 1984.(In press.)

11 Pedersen JH, Stadil F, Fahrenkrug J. Preparation of ${ }^{125} \mathrm{I}-\left(\right.$ Tyr 3)-and ${ }^{125} \mathrm{I}$-(Tyr 11) neurotensin for radioimmunoassay. Scand J Clin Lab Invest 1983; 43: 483-91.

12 Baron JH. The relationship between basal and maximum acid output in normal subjects and patients with duodenal ulcer. Clin Sci 1963; 24: 357-70.

13 Öbrink KJ. Theoretical considerations concerning gastric inhibition. Scand J Gastroenterol 1976; 11, suppl. 42: 7-13.

14 Andersson S, Rosell S, Sjödin L, Folkers K. Inhibition of acid secretion from vagally innervated and denervated gastric pouches by $\left(\mathrm{Gln}^{4}\right)$-neurotensin. Scand J Gastroenterol 1980; 15: 253-6. 
15 Andersson S, Chang D, Folkers K, Rossell S. Inhibition of gastric acid secretion in dogs by neurotensin. Life Sci 1976; 19: 367-70.

16 Carraway R, Leeman SE. Characterization of radioimmunoassayable neurotensin in the rat. Its differential distribution in the central nervous system, small intestine and stomach. J Biol Chem 1976; 251: 7045-52.

17 Christiansen J. The possible physiological role of glucagon on gastroesophageal function. In: Picazo J, ed. Glucagon in gastroenterology and hepatology. Pharmacological, clinical and therapeutic implications. Lancaster, UK: MTP Press Limited, 1982: 69-80.

18 Melrose AG. Effect of glucagon on gastric secretion in man. Gut 1960; 1: 142-5.

19 Olsen PS, Kirkegaard P, Holst JJ, Christiansen J. Vagal control of glucagon-induced inhibition of gastric acid secretion in duodenal ulcer patients. Scand $J$ Gastroenterol 1982; 17: 629-32. 